\title{
State of Comorbidity in Patients with Hypertension under Conditions of Industrial Production
}

\author{
Valerii Levchenko, Ihor Vakaliuk, Liubov Hordiichuk, Anna Ovchar*, Mariana Maksymiak, \\ Ivanna Svystun, Lesia Levchenko
}

\begin{abstract}
Comorbid conditions in patients with hypertension on the background of occupational hazards create additional problems in the treatment of hypertension. An analysis of working conditions in 76 workers of the Ivano-Frankivsk armature factory who underwent regular medical check-ups regarding first-/second-degree hypertension (the main group) showed that they were exposed to occupational hazards of chemical (acrolein carbon, iron oxide, chromium, fluorine compounds, sulfuric acid) and physical (high temperature, noise, vibration, electromagnetic radiation, dust) nature for a long period of time (from 4 to 11 years). Comorbid conditions were most often observed among the patients of the main group as compared to the patients of the control group $(n=17)$, who were not exposed to occupational hazards $-82.06 \%$ and $73.34 \%$ of cases, respectively. In the patients of the main group, chronic bronchitis was detected in $26.56 \%$ of cases and coronary artery disease was diagnosed in $25.09 \%$ of cases as compared to $8.33 \%$ and $18.34 \%$ of cases in the control group. At the same time, $38.89 \%$ of hypertensive patients of the main group were diagnosed with chronic bronchitis and concomitant coronary artery disease, which were not observed in the patients of the control group. The patients of the main group were more likely to have dyslipidemia, left ventricular hypertrophy, aortic fibrosis, hypertensive retinopathy as compared to the patients of the control group. In the control group, patients with overweight and type 2 diabetes mellitus prevailed. Quality of life assessment using the 36-Item Short Form Health Survey among the patients of the main group revealed a significant decrease in the indicators of physical and vital activity, fulfillment of daily professional duties. In the control group, a worsening emotional state prevailed.
\end{abstract}

\section{Keywords}

comorbid conditions; arterial hypertension; harmful factors

Ivano-Frankivsk National Medical University, Ukraine

*Corresponding author: annadoctor70@gmail.com

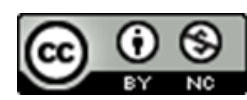

Copyright @ Valerii Levchenko, Ihor Vakaliuk, Liubov Hordiichuk, Anna Ovchar, Mariana Maksymiak, Ivanna Svystun,

Lesia Levchenko, 2020

The objective of the research was to carry out an assessment of comorbidity among patients with arterial hypertension $(\mathrm{AH})$, namely the employees of the armature factory in Ivano-Frankivsk, being exposed to industrial hazards.

\section{Materials and Methods}

There were studied the outpatient and dispensary records and other medical documentation of 93 first-/second-degree hypertensive patients who underwent regular medical check-ups during 20162018 in the primary healthcare unit of the IvanoFrankivsk armature factory. Seventy-six patients, who worked in production workshops, comprised the main group; among them, there were 47 pa- 
tients with first-degree $\mathrm{AH}$ and 29 patients with second-degree $\mathrm{AH}$. The control group consisted of $17(22.67 \%)$ patients with $\mathrm{AH}$, namely the employees of the factory administration, departments of marketing, supply, technical control, accounting, and security; among them, 12 individuals were diagnosed with first-degree $\mathrm{AH}$, while 5 patients suffered from second-degree AH.

The patients of both groups had previously undergone clinical examination (outpatient and/or in a hospital), during which their heart rate, blood pressure (BP), anthropometric data (body mass index, abdominal circumference), results of electrocardiogram (ECG) and echocardiography, abdominal ultrasound, spirometry, chest radiography were evaluated by standard requirements. The results of blood tests for sugar, cholesterol, creatinine, aspartate aminotransferase (AST) /alanine aminotransferase (ALT), C-reactive protein (CRP), etc. were evaluated as well. The diagnosis of hypertension was made in accordance with the recommendations of the Association of Cardiologists of Ukraine for the Prevention and Treatment of Hypertension and 2018 European Society of Hypertension (ESH) /European Society of Cardiology (ESC) Clinical Practice Guidelines for the Management of Arterial Hypertension $[11,14]$.

The analysis of working conditions among the workers of the main group showed that, depending on their profession (heat treaters, blacksmiths, welders, those working with sanders, tool grinders, hot metal locksmiths, galvanisers, turners, millers), they were systematically exposed to acrolein carbon, white corundum, nitrogen dioxide, iron oxide, manganese, silicon, chromium, fluorine compounds, sulfuric acid, chromic anhydride. In addition, a significant part of the workers in this group were exposed to excessive temperature, noise, vibration, staying in a forced position for a long period of time. Workers of the administration and security (the control group) were more often exposed to nonionizing radiation of personal computers, emotional stress, working at night (desynchronosis).

In both groups, the patients were assessed for quality of life using the 36-Item Short Form Health Survey (SF-36), which included the following in- dicators: physical functioning (PF), role physical (RP), bodily pain (BP), general health $(\mathrm{GH})$, vitality (VT), social functioning (SF), role emotional (RE), mental health $(\mathrm{MH})$ [5].

The average values of the examined patients were determined using the analysis package in $\mathrm{Mi}$ crosoft Office Excel. The variational and statistical analysis method using the statistical software Statistica v 6.1 (USA) was applied to assess the degree of reliability of the research results as well.

\section{Results and Discussion}

The main group included only men at the age of 39-62 years with $11.45 \pm 0.51$ years of work experience. The minimal occupational exposure to harmful substances was 4-11 years. Among the patients of the main group ( $n=76)$, according to the data of outpatient and dispensary medical records, in 47 patients with first-degree $\mathrm{AH}$, initial office systolic blood pressure (SBP) was $146.53 \pm 0.79$ $\mathrm{mm} \mathrm{Hg}$ and diastolic blood pressure (DBP) was $86.55 \pm 0.94 \mathrm{~mm} \mathrm{Hg}$; in 29 patients with seconddegree AH, SBP was $164.52 \pm 0.86 \mathrm{~mm} \mathrm{Hg}$, while DBP was $99.48 \pm 1.25 \mathrm{~mm} \mathrm{Hg}$. Among the patients of the control group $(\mathrm{n}=17)$, there were 7 $(41.18 \%)$ men and $10(58.82 \%)$ women at the age of 42-64 years. In 12 patients with first-degree $\mathrm{AH}$, initial SBP was $145.75 \pm 1.69 \mathrm{~mm} \mathrm{Hg}$ and DBP was $86.75 \pm 1.27 \mathrm{~mm} \mathrm{Hg}$; in 5 patients with second-degree AH, SBP was $163.0 \pm 1.74 \mathrm{~mm} \mathrm{Hg}$ and DBP was $100.8 \pm 1.66 \mathrm{~mm} \mathrm{Hg}$.

The revealed baseline BP parameters in the main and control groups did not differ significantly.

In the patients of the main group, before beginning their professional activity, BP was within normal limits. At the same time, they had no documented pathology of the heart, respiratory system, kidneys, and peripheral vessels.

According to the study, among the patients of the main group, dyslipidemia was detected in $48.94 \%$ of cases; left ventricular hypertrophy was found in $27.63 \%$ of cases; aortic fibrosis was found in $19.74 \%$ of patients; overweight was observed in $47.37 \%$ of patients; hypertensive retinopathy was seen in $7.89 \%$ of cases. In addition, $31.58 \%$ of 
patients had a history of smoking, and $21.05 \%$ of patients consumed alcohol on a regular basis (moderate consumption).

The patients of the control group were diagnosed with dyslipidemia (31.58\%), left ventricular hypertrophy $(23.53 \%)$, aortic fibrosis $(11.76 \%)$ as well. In addition, $23.53 \%$ of patients had a history of smoking, and $11.76 \%$ of patients consumed alcohol moderately. In addition, the patients of the control group were diagnosed with hypodynamia $(88.24 \%)$, overweight $(52.93 \%)$ and obesity (14.67\%).

The effect of occupational hazards on the patients of the main group was as follows (Fig. 1). The patients with first-degree AH most often noted noise and vibration (72.34\%), dust (65.96\%); $57.45 \%$ and $40.43 \%$ of patients, respectively noted a forced position during the day and the effects of high temperature in the workplace. The patients with seconddegree AH often complained of the effects of vibration, dust, noise - in 58.62\%, 55.17\% and 51.72\% of cases, respectively.

Some patients of the main group who suffered from first-degree $\mathrm{AH}(21.28 \%)$ and those with seconddegree AH (27.59\%) tried to avoid excessive exposure to certain occupational hazards (high temperature, excessive noise, vibration, etc.), which were associated with deterioration of their well-being in the workplace, treatment in the medical unit, increase in BP, additional intake of antihypertensive agents. A similar pattern was found in patients with comorbid (polymorbid) conditions [8].

Thus, patients with $\mathrm{AH}$ were diagnosed with comorbid (polymorbid) conditions in the form of chronic bronchitis, coronary artery disease (CAD), type 2 diabetes mellitus (DM), obesity, pathology of peripheral vessels, polyarthritis, etc. (Table 1).

Among the patients of the main group, comorbid (polymorbid) conditions were observed in $74.47 \%$ of patients with first-degree $\mathrm{AH}$, while in $25.53 \%$ of cases, concomitant pathology was not found. In the patients with second-degree $\mathrm{AH}$, similar indicators were found in $89.66 \%$ and $10.34 \%$ of patients, respectively. Among the patients of the control group, comorbid (polymorbid) conditions were observed in $66.67 \%$ of patients; in the remaining patients of this group, concomitant pathology was not revealed. Among the patients with second-degree $\mathrm{AH}$, comorbid (polymorbid) conditions were observed in $80 \%$ of cases, while in $20 \%$ of cases, concomitant pathology was not found.

Thus, comorbid conditions were most commonly found in the patients of the main group (82.06\%), while in the patients of the control group, they occurred significantly rarer $(73.34 \%)$.

According to the results obtained, chronic bronchitis was detected in 20 patients of the main group $25.53 \%$ of patients with first-degree $\mathrm{AH}$ and $27.59 \%$ of patients with second-degree AH. Among them, $16.67 \%$ patients with first-degree $\mathrm{AH}$ and $25 \%$ of patients with second-degree $\mathrm{AH}$ were diagnosed with COPD. Only $4(20 \%)$ patients of the main group were found to be heavy smokers, that indicated the role of occupational hazards in the formation of changes in the bronchopulmonary system. At the same time, only one patient of the control group had chronic bronchitis.

Verification of chronic bronchitis was performed according to standard requirements on an outpatient and inpatient basis according to complaints, medical and life history, X-ray data, spirometry, and laboratory findings (blood, urine, sputum).

Disorders of the bronchopulmonary apparatus under conditions of industrial production are known to be associated with the direct effect of harmful compounds, oxidative stress, systemic inflammation, hypoxemia, which, in turn, may affect the metabolism of vasoactive substances, microcirculation $[4,6,12]$. There has been proven the role of hypoxia in the development of systemic hypertension in patients with chronic bronchitis, as it promotes the activity of the sympathetic-adrenal system, the angiotensin-converting enzyme. Moreover, the role of vasoactive metabolic disorders in the lungs (endothelin I, angiotensin II, histamine, kinin, serotonin, etc.) in the genesis of hypertension is not excluded. The involvement of renin in the regulation of blood flow to the lungs was experimentally proven as well $[1,4,10]$.

Thus, long-term damaging effect of physicochemical factors on the bronchopulmonary apparatus and endothelial cells simultaneously can con- 


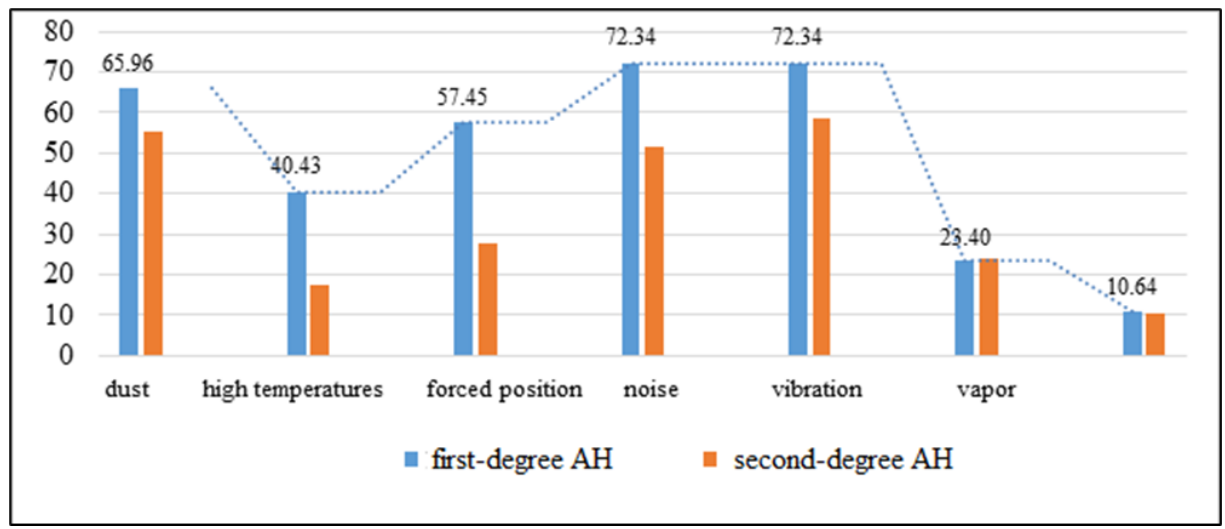

Figure 1. Nature of occupational hazard influence on hypertensive patients of the main group ( $\mathrm{n}=76)$.

Table 1. Comorbid (polymorbid) conditions detected in hypertensive patients of the main and control groups.

\begin{tabular}{|c|c|c|c|c|}
\hline \multirow{3}{*}{ Comorbidities } & \multicolumn{4}{|c|}{$\mathrm{AH}$} \\
\hline & \multicolumn{2}{|c|}{ Main group (\%) } & \multicolumn{2}{|c|}{ Control group (\%) } \\
\hline & $\begin{array}{c}\text { first- } \\
\text { degree } \\
(n=47)\end{array}$ & $\begin{array}{l}\text { second- } \\
\text { degree } \\
(n=29)\end{array}$ & $\begin{array}{c}\text { first- } \\
\text { degree } \\
(n=12)\end{array}$ & $\begin{array}{c}\text { second- } \\
\text { degree } \\
(n=5)\end{array}$ \\
\hline $\begin{array}{l}\text { Chronic bronchitis } \\
\quad \text { (including COPD) }\end{array}$ & $\begin{array}{c}25.53 \\
(16.67)\end{array}$ & $\begin{array}{l}27.59 \\
(25.0)\end{array}$ & 8.33 & \\
\hline Chronic CAD & 19.15 & 31.03 & 16.67 & 20 \\
\hline Type 2 DM & 2.13 & 10.34 & 8.33 & 40 \\
\hline Peripheral vascular arteriosclerosis & 8.51 & 6.90 & & \\
\hline Varicose veins & 8.51 & 10.34 & & 20 \\
\hline Chronic radiculitis & 10.64 & 24.14 & 16.67 & 20 \\
\hline Obesity & 4.26 & 6.90 & 8.33 & 20 \\
\hline Chronic prostatitis & & 3.45 & & \\
\hline Duodenal ulcer & 2.13 & & & \\
\hline Polyarthritis & & 3.45 & 16.67 & \\
\hline Chronic pyelonephritis & 2.13 & 3.45 & 8.33 & \\
\hline Chronic cholecystitis & 2.13 & & 16.67 & \\
\hline Uterine fibromyoma & & & 8.33 & 20 \\
\hline
\end{tabular}

Note: COPD - chronic obstructive pulmonary disease.

tribute to changes in pulmonary ventilation, increase and stabilization of BP under conditions of industrial production $[2,12]$.

In addition, $19.15 \%$ of first-degree hypertensive patients and $31.03 \%$ of second-degree hypertensive patients of the main group were diagnosed with stable angina pectoris functional class (FC) I-II, atherosclerotic cardiosclerosis. At the same time,
$38.89 \%$ of hypertensive patients were diagnosed with chronic bronchitis and concomitant CAD. In the control group, the last variant of comorbidity was not detected. The diagnosis of CAD was made according to subjective and objective symptoms, medical history, ECG results, echocardiography, laboratory diagnostics, which were obtained during examination in a hospital or polyclinic. 
The coexistence of $\mathrm{AH}$ and CAD indicated a high cardiovascular risk among the patients of the main group.

Type $2 \mathrm{DM}$ was more commonly seen in the patients of the control group, while peripheral artery lesions were observed in the patients of the main group. It should be noted that among first-degree and second-degree hypertensive patients with vascular lesions, CAD was diagnosed in $75 \%$ and $100 \%$ of cases, respectively.

The influence of harmful factors on endothelial cells is known to contribute to the formation of their dysfunction, arteriosclerosis, increased stiffness and resistance of peripheral blood vessels, reduction in oxygen tension in the blood and tissues, which stimulates chemoreceptors of arterial and venous neurons, efferent sympathetic vasoconstriction [3, 7,9].

Comorbid conditions in both groups were found to depend on the patients' age (Fig. 2).

Thus, in the age groups of 41-50 years and 5160 years, comorbid conditions prevailed among the patients of the main group (high confidence level $\left(\mathrm{R}^{2}\right)$ along the trend line). Among the patients at the age of $\geq 61$ years, the incidence of comorbid conditions was the same in both groups (100\%). The results obtained indicated that the effect of occupational hazards can be an additional age-related change factor, that contributes to the increase of comorbidity parameters in the main group of patients.

Analysis of the efficacy of antihypertensive treatment according to the patients' referrals to the medical unit of the armature factory and regular medical check-ups showed that the therapy applied did not significantly affect the clinical course of concomitant diseases in both groups on the background of following doctor's recommendations by the majority of patients. The issue of reaching target BP in the patients of the main and control groups needs further study. It can only be noted that all the patients in the main group received combination antihypertensive therapy.

At the same time, quality of life assessment with the SF-36 questionnaire among the patients of the main and control groups showed a decrease in the indicators of its individual scores [5]. In the main group, the decrease in physical and vital activity, the fulfillment of daily professional duties, the restriction of the patient's activity through pain etc. prevailed. In the control group, a worsening emotional state prevailed (Fig. 3).

Nowadays, therapists and family physicians, unfortunately, do not pay attention to the problem of comorbidity timely and efficiently, and treat the underlying disease paying no attention to the patient's life history, comorbid conditions, the correlation of concomitant pathology and the general healing of the body; however, there are no separate diseases. Treatment of comorbid (polymorbid) conditions requires adherence to certain tactics of rational pharmacotherapy, high professionalism in clinical context and a wide range of knowledge in the field of related specialties $[8,9]$.

At present, there are no clear diagnostic and therapeutic approaches that allow doctors to identify comorbid conditions and the methods of their effective correction timely. In this category of patients, it is necessary to determine the degree and nature of functional disorders, potential morphological changes in nosological forms revealed timely. Therefore, the appearance of non-typical or even slightly expressed symptom on the background of $\mathrm{AH}$ treatment requires special attention and an additional examination to determine its origin, as the long-term impact of occupational hazards can serve as one of the triggers for the formation of comorbid diseases, including AH. The prognosis of the disease is determined by the level of BP, as well as the presence and severity of concomitant risk factors, diseases.

Therefore, in case of long-term exposure to occupational hazards, breaking the chain of pathogenic events at its various stages with the help of certain medications and non-drug treatments will allow to prevent or slow down the formation of cardiovascular risks, reduce the manifestations of concomitant diseases and their complications, improve the patients' quality of life [13]. On the other hand, the treatment of comorbidity often contributes to polypharmacy, thereby increasing the risk of developing undesirable side effects of drugs, especially in elderly patients. These are often regarded as a 


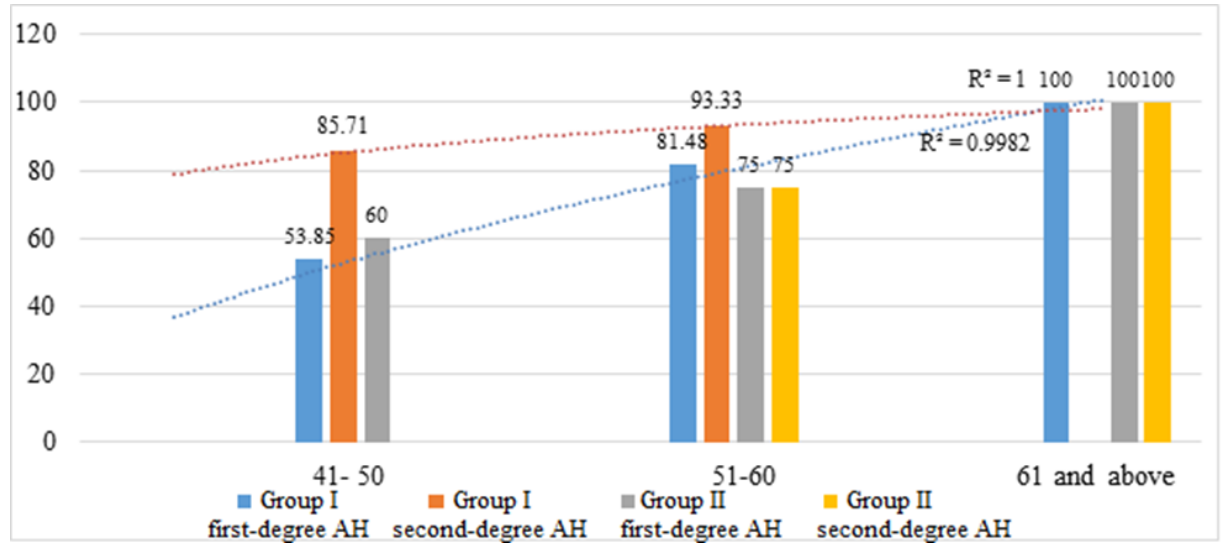

Figure 2. Incidence of comorbid conditions in patients with $\mathrm{AH}$ depending on age in the main and control groups $(\%)$.

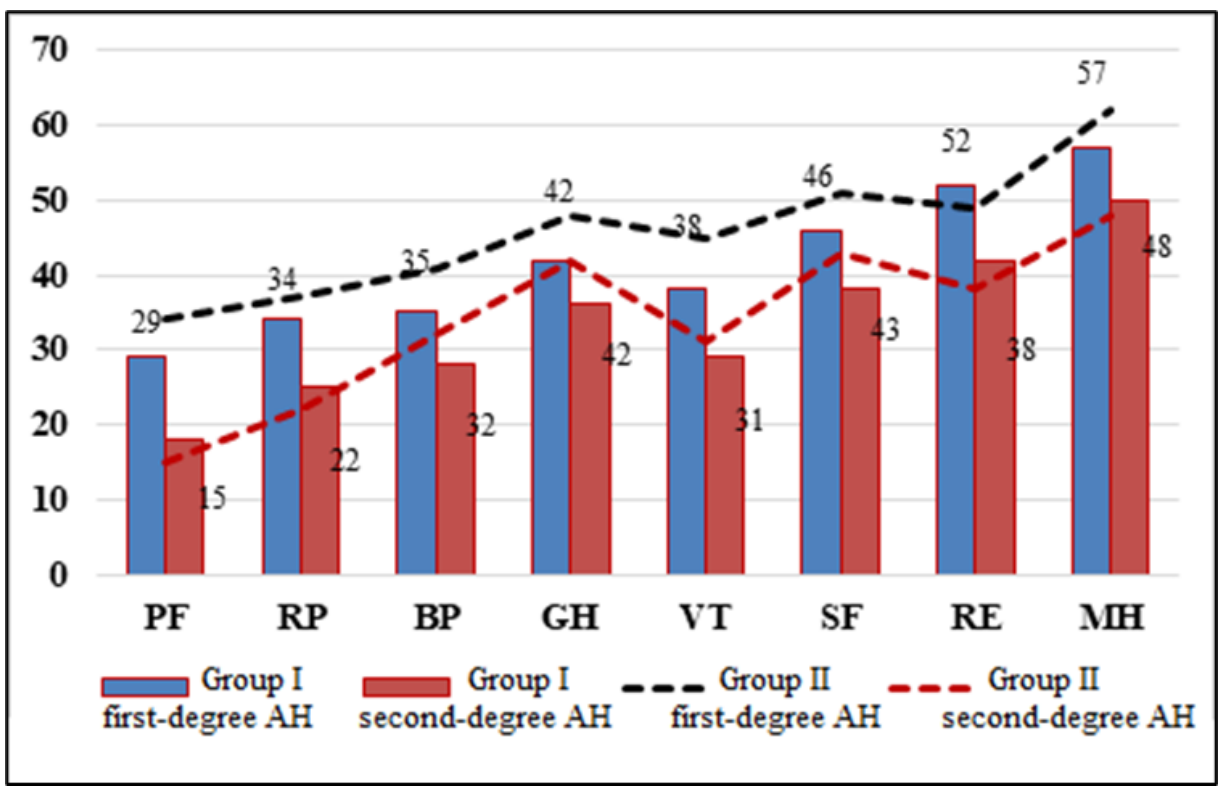

Figure 3. Dynamic changes in quality of life indicators according to the SF-36 questionnaire in hypertensive patients of the main and control groups $(\%)$.

new manifestation of comorbidity that causes more drugs to be prescribed. Modern international randomized trials mainly solve the issue of comparing the effectiveness of different drug classes or their combinations in treatment of hypertension. However, the possibility of using the results of these studies in real clinical practice is often limited, since comorbid conditions are not taken into account in the protocols for managing patients with $\mathrm{AH}$; therefore, this situation requires further clinical studies.

\section{Conclusions}

1. It is necessary to comply with the requirements of the Order and the Systematic Provisions for determining the professional suitability of workers with hypertension under the influence of occupational hazards.

2. If patients are diagnosed with first-/seconddegree $\mathrm{AH}$, they should be referred to the appropriate dispensary group with a survey once a year at the place of medical care (in the absence of special indications). 
3. Early clinical examination of hypertensive patients with comorbidity will allow physicians to determine the treatment strategy for coexistent diseases at different stages of their development timely, as well as to prevent the risks of possible cardiovascular events.

4. Among the dispensary group of workers of the Ivano-Frankivsk armature factory, who were exposed to occupational hazards, the most common comorbid conditions in hypertension were chronic bronchitis, CAD, pathology of peripheral vessels and kidneys.

5. In industrial production, the main direction of protecting the workers' health is to reduce the impact of occupational hazards on the workers by improving the logistics of preventive organizational and technical and medical measures.

\section{Prospects of Further Researches}

The study of the features of individual antihypertensive therapy in patients with manifestations of comorbidity against the background of occupational hazards is promising.

\section{Conflict of Interest}

The authors stated no conflict of interest.

\section{Financial Disclosure}

The authors declared no financial support.

\section{References}

[1] Babanov SA, Baraeva RA, Budash DS. Lesions of cardiovascular system in the practice of a pathologist. World of Transport and Transportation. 2016; 14 (4): 106-111. DOI: https://doi.org/10. 21145/2499-9954-2016-4-106-111

[2] Basanets AV, Andruschenko TA. Cardiovascular diseases under the action of occupational factors. Ukrainian Journal of Occupational Health. 2010; 22: 71-81. DOI: https://doi.org/10.33573/ ujoh2010.02.071

[3] Belyaev OV, Kuznetsova ZM. Kompleksnyy analiz faktorov riska arterialnoy gipertoniyi $\mathrm{u}$ lits, zanyatykh upravlencheskim trudom. Kardiologiya. 2006; 4: 20-23.

[4] Vertkin AL, Skotnikov AS, Tikhonovskaya $\mathrm{EYu}$ et al. Komorbidnost pri KHOBL: rol khronicheskogo sistemnogo vospaleniya. RMZH " Meditsinskoye obozreniye". 2014; 11: 8-11.

[5] Dauletbakova DN. Izucheniye kachestva zhizni bolnykh arterialnoy gipertenziyey na osnovaniyi ispolzovaniya oprosnika SF-36. Molodoy uchenyy. 2018; 23 (209): 23-28.

[6] Zerbino DD, Solomenchuk TM. Development of Acute Coronary Pathology in Young Patients: Environmental Concept and Epidemiological Arguments in its Support. Medicine of Ukraine. 2010; 10 (1): 49-56.

[7] Lopatin YuM, Ilyukhin OV. Kontrol zhestkosti sosudov. Klinicheskoye znacheniye i sposoby korrektsiyi. Serdtse. 2007; 3 (35): 128-132.

[8] Nesen AO. Khronichni neinfektsiini zakhvoriuvannia: aktsent na komorbidnist i pidvyshchenyi kardiovaskuliarnyi ryzyk. Ukrainian Therapeutical Journal. 2014; 2: 2632.

[9] Oganov RG, Simanenkov IV, Bakulin IG et al. Comorbidities in clinical practice. Algorithms for diagnostics and treatment. Cardiovascular Therapy and Prevention. 2019; 18 (1): 5-66. DOI: https://doi.org/10 . $15829 / 1728-8800-2019-1-5-66$

[10] Ostroumova OD, Kochetkov AI, Guseva TF. Blood pressure variability in hypertension associated with coronary heart disease: prognostic value and management approaches. Arterial Hypertension. 2018; 24 (2): 246-256. 
DOI: https://doi.org/10.18705/

$1607-419 x-2018-24-2-246-256$

[11] Rekomendatsii Ukrainskoii asotsiatsii kardiolohiv z profilaktyky ta likuvannia arterialnoi hipertenzii. Kyiv; c2011. 84p.

[12] Shamukhamedova NSh, Agzamova UA. Arterial hypertension and chronic obstructive pulmonary disease - problems of choice of therapy. Colloquium-journal. 2019; 2 (26): 15-17. [published in Russian]

[13] Schirpenbach C, Reincke M. Epidemiology and etiology of therapy-resistant hypertension. Internist (Berl). 2009; 50 (1): 716. DOI: https://doi.org/10.1007/ s00108-008-2194-9 [PMid:19043688]

[14] Whelton PK et al. 2017 High Blood Pressure Clinical Practice Guideline: Executive Summary. c2017. 401p.

Received: 2020-01-02

Revised: 2020-05-20

Accepted: $2020-05-30$ 